\title{
走査放電軸成形法における軸直径と消耗比
}

\author{
平尾篤利* 谷貴幸** 李珠瓊* 毛利尚武*** 齋藤長男 $* * * *$
}

\section{Relationship between electrode diameter and wear ratio in scanning electrical discharge machining}

\author{
Atsutoshi Hirao, Takayuki Tani, Ju-Kyoung Lee, Naotake Mohri and Nagao Saito
}

\begin{abstract}
In this study, we propose a new micropin forming method in which the forming plate can be stationary while the rotating electrode moves towards the forming plate. As the processing area in this method is large, a higher removal rate is possible compared with the WEDG micropin forming method. Forming by this method is easily accomplished for the micropins of less than $50 \mu \mathrm{m}$ under a low electrical discharge conditions. In this study, we aimed to obtain the desired electrode diameter by means of scanning electric discharge machining. The electrode diameter decreased rapidly with increasing machining time, and it was difficult to control the micropin diameter by controlling only the machining time. Therefore, we conducted micropin forming by controlling the indicator scanning distance during machining. The results are strongly dependent on the ratio of consumption of the forming plate and the electrode. We investigated the relationship between the electrode diameter and the scanning distance referring to the experimental values and the theoretical ratio based on the consumption theory. Micropin diameters of up to $150 \mu \mathrm{m}$ were obtained. The experimental values were found to be in good agreement with the theoretical values. Since the wear ratio was changed owing to the miniaturization of the electrode, there is a difference between the theoretical and experimental values.
\end{abstract}

Key words: Micropin, Scanning EDM, Electrode wear ratio

1. 緒言

放電加工法は，加工反力が極めて小さいため, 微細加工分野において大きな効果を発揮する．微 細加工に用いる微細軸成形法として，著者らは Fig. 1 に示すように電極（以後，軸）と被加工物 （以後，成形プレート）を配置し，軸を回転させ ながら成形プレート側へと走査する方法を提案し た 1)。この方法は, WEDG 法 2)，3)，逆放電法 ${ }^{4)}$,

\footnotetext{
* 工学院大学(東京都八王子市犬目 139)

*** 筑波技術大学(茨城県つくば市天久保 4-3-15)

*** 大学評価・学位授与機構 (東京都小平市学園西 町 1-29-1)

**** S.N.技術研究所(愛知県春日井市岩成台 9-12-12)
}

加工穴を利用した放電微細軸成形法 5)などの軸成 形法と比較して放電面積が広く高い加工速度が得 られる. Fig. 2 に加工時間に対寸る軸直径の変化

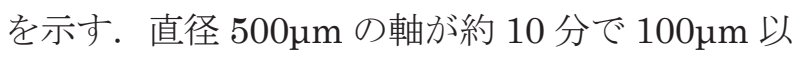
下に細くなっていることが確認できる，また，放 電条件を小さく設定することで $50 \mu \mathrm{m}$ 以下の軸も 容易に成形できる.

この走査放電加工法を拡張したツイン電源方式 を適用したスリット間隙追跡走査放電加工を用い ることで，直径 $300 \mu \mathrm{m}$ の軸を約 3 分で $50 \mu \mathrm{m}$ の 軸直径成形を実現している ${ }^{6}$ )，7)。スリット間隙を 追跡することで任意の軸直径の微細軸成形を可能 としているが，この方法では特別な制御が必要と 


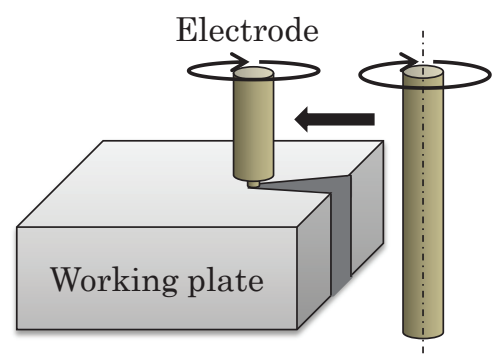

Fig. 1 Forming of micropin by scanning EDM

なる。

本研究では，より簡便な制御法を用いた走査放 電加工法によって所望の軸直径を得ることを目的 としている．任意の軸直径を得るためには，直接 計測が最も確実な方法であるが，加工中に直接測 定はできない。このため加工時間による制御を試 みたが，軸直径の変化に伴って変化する放電頻度 の影響によって十分な精度を得ることは困難であ った．そこで，加工時の走查距離を制御の指標と した軸成形を実施した。この制御方法による軸成 形特性および精度について検討し, その課題につ いて考察する.

\section{2. 走查放電加工法を用いた加工特性}

\section{1 加工時間による軸直径の制御}

走查放電加工法において所望とする軸直径を得 るためには，加工時間によって軸直径を制御する 方法が考えられる. Fig. 3 に一定の加工条件で, 単位時間当たりの除去体積を一定とみなした場合 の軸成形履歴（計算值）および実測した放電頻度 を示す．加工条件を Table1 に示寸．軸には直径 $500 \mu \mathrm{m}$ の超硬合金を，成形プレートに厚さ $1 \mathrm{~mm}$ の銅を用い，放電回路は $\mathrm{RC}$ 回路とした．軸直径 は, ビデオマイクロスコープ (分解能: $1 \mu \mathrm{m} / 1 \mathrm{pixel}$ ) で取り込んだ画像から計測した。軸直径と加工時 間の関係式は Fig.3 に示したとおりである.ただ し, $r$ : 軸半径, $r_{0}$ : 初期の軸半径, $V$ : 単位時間 あたりの除去体積, $l:$ 軸長さ, $t:$ 加工時間であ る。なお，計算に用いた単位時間当たりの体積減 少量 $V$ は, $500 \mu \mathrm{m}$ から $400 \mu \mathrm{m}$ 程度まで加工した 際の実測值を用いた。

Fig.3 内に示した関係式からも分かるように, 軸直径は時間の経過に伴って急激に細線化する.

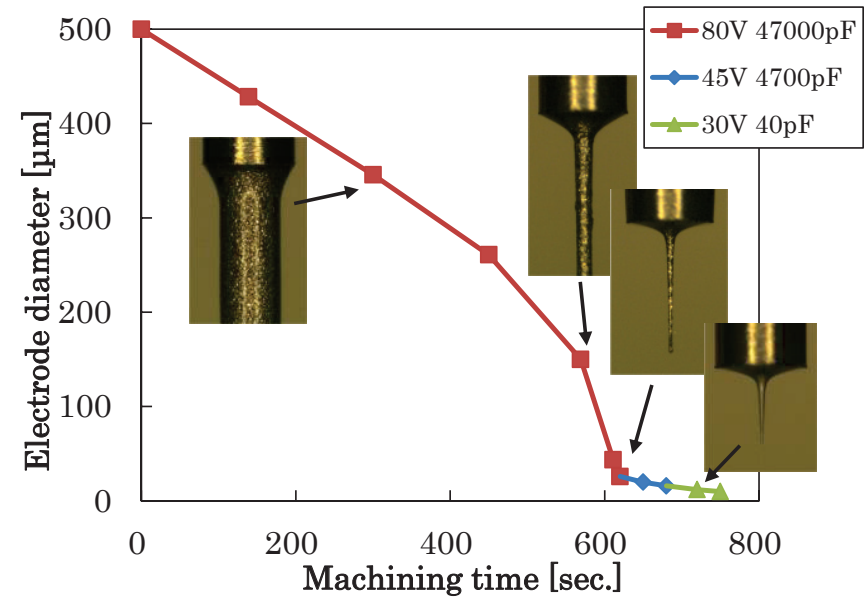

Fig. 2 Relation between diameter and machining time

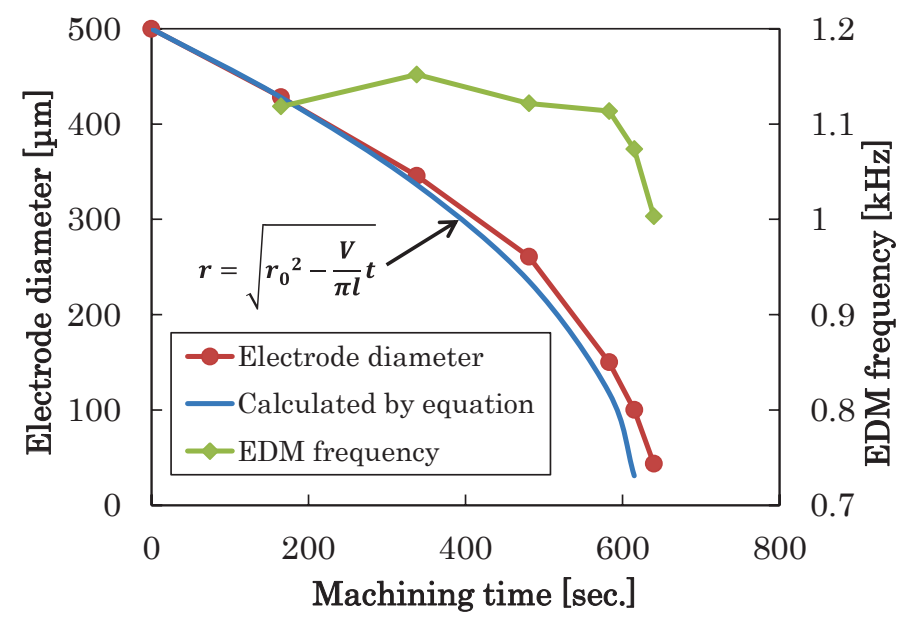

Fig. 3 Relation between diameter and machining time with EDM frequency

Table1 Experimental conditions

\begin{tabular}{|c|c|}
\hline Electrode & WC-Co $(\phi 500 \mu \mathrm{m})$ \\
\hline Working plate & $\begin{array}{c}\mathrm{Cu}(l=1 \mathrm{~mm}) \\
\text { Zinc alloy }(l=1 \sim 5 \mathrm{~mm})\end{array}$ \\
\hline Polarity & $\begin{array}{c}\text { Electrode }(-) \\
\text { Working plate }(+)\end{array}$ \\
\hline Open circuit voltage, $\mathrm{E}$ & $80 \mathrm{~V}$ \\
\hline Capacitance, $\mathrm{C}$ & $47000 \mathrm{pF}$ \\
\hline Charging resistance, $\mathrm{R}$ & $0.5,1.0,2.0 \mathrm{k} \Omega$ \\
\hline Rotation & $4000 \mathrm{rpm}$ \\
\hline
\end{tabular}

また, Fig.3 において加工時間 600 秒を境に, 放 電頻度が急激に低下寸る傾向を示した。放電頻度 の低下は, 放電面積の減少が一因として考えられ, 


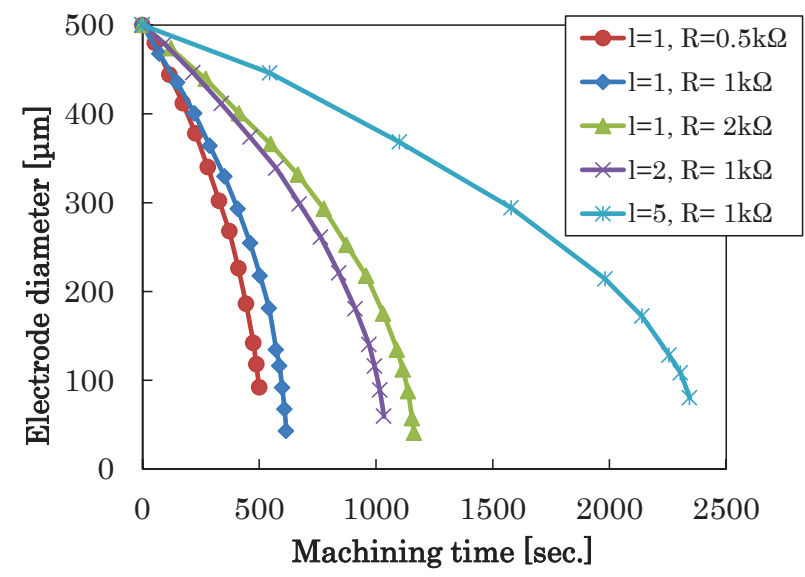

Fig. 4 Relation between diameter and machining time (Zinc-alloy)

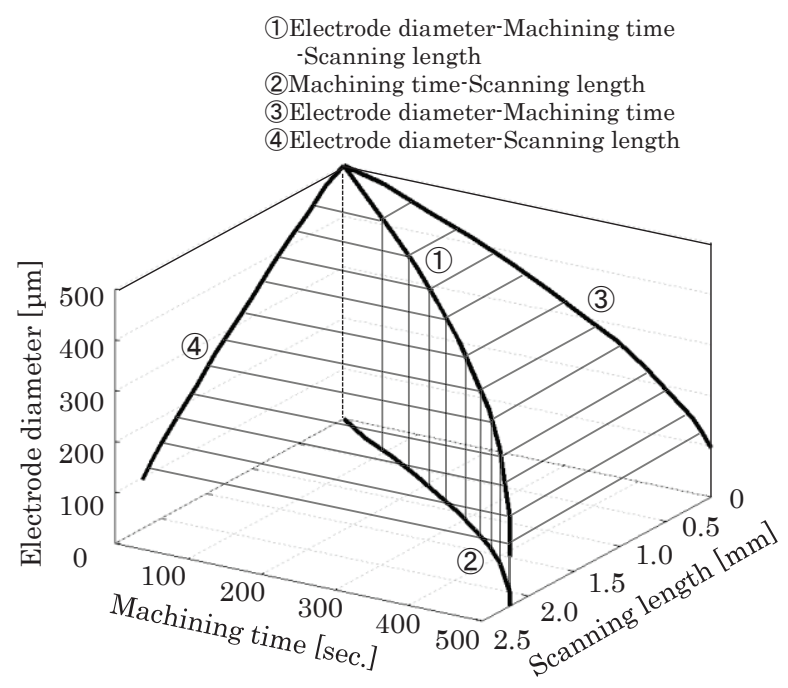

Fig. 5 Relation between diameter, machining time and scanning length (Zinc-alloy)

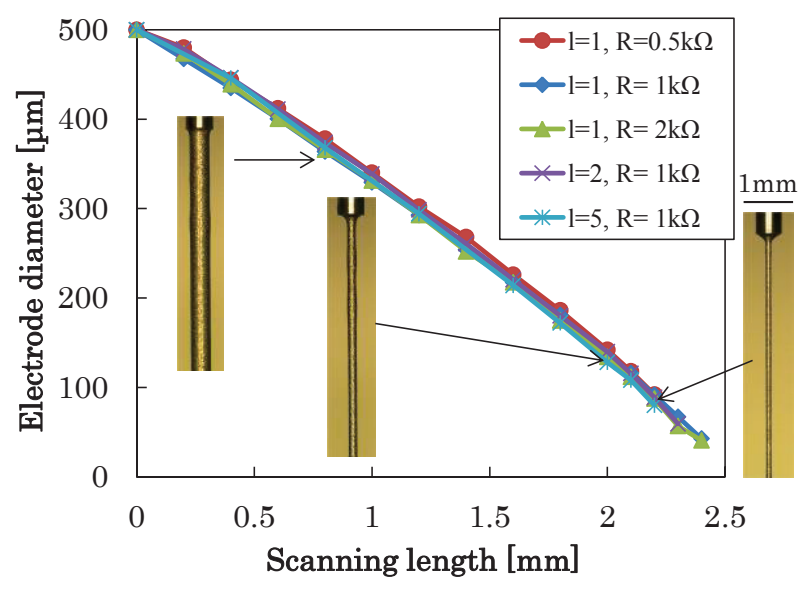

Fig. 6 Relation between diameter and scanning length (Zinc-alloy)
これによって実際の軸成形履歴は計算值からは外 れていくことが分かる. Fig. 4 には電気条件, 軸 の成形長さを変化させた場合の軸成形履歴を示す. 加工条件によって，軸成形速度が変化しており， 仮に計算值を基準として軸直径を制御する場合に は，単位時間当たりの体積減少量 $V$ は各条件によ って個別に設定しなければならないことになる。 これらの要因を考慮すると, 加工時間によって軸 直径を推定することは極めて困難であり，現実的 な方法ではない.

\section{2 走査距離, 加工時間と軸直径の関係}

走查放電加工においては，加工時間の経過に伴 って, 軸直径と共に走查距離も変化する。この関 係を Fig. 5 の 3 次元グラフ(1)に示す.グラフは Fig. 4 に示した, $l=1, \mathrm{R}=0.5 \mathrm{k} \Omega$ を用いた. グラフ (2)には加工時間と走查距離の関係，グラフ(3)はこ れまでに示した加工時間に対する軸直径の関係を それぞれ示す．グラフ(4)は，走査距離と軸直径の 関係を示す。

加工時間を変数としたグラフ(3)においては，先 に述べたように時間の経過に伴って軸直径は急激 に細線化している。これに対して，グラフ(4)で示 した走査距離と軸直径の関係はほぼ直線的な関係 を示しており，この直線的な関係は軸直径を推定 する変数として有用となる可能性がある.

\section{3 走査距離による軸直径の制御}

本節では，走查距離による軸直径の制御の可能 性について検討する. Fig.4 に示したように，加 工時間と軸直径の関係は，加工条件によって大き く変化する．同様の加工条件において，走查距離 と軸直径との関係で整理した結果を Fig. 6 に示す. 走査距離を変数とした軸成形履歴は，加工条件を 変化させてもほとんど影響しない結果となった. 加工条件は充電抵抗をパラメータとしたことから， 走查距離と成形される軸直径の関係には，放電頻 度は依存しないことが分かる。また，成形する軸 の長さにも依存しない結果となり，走査距離を変 数とした軸成形履歴は消耗率が支配的となると考 えられる。

走查放電加工後の成形プレートは軸の微細化に 

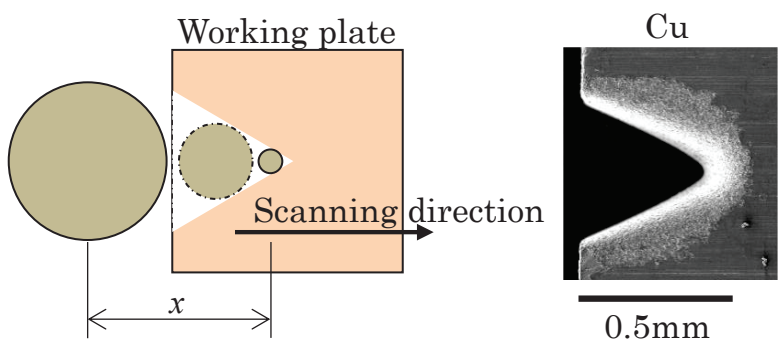

Fig. 7 Scanning EDM process to copper

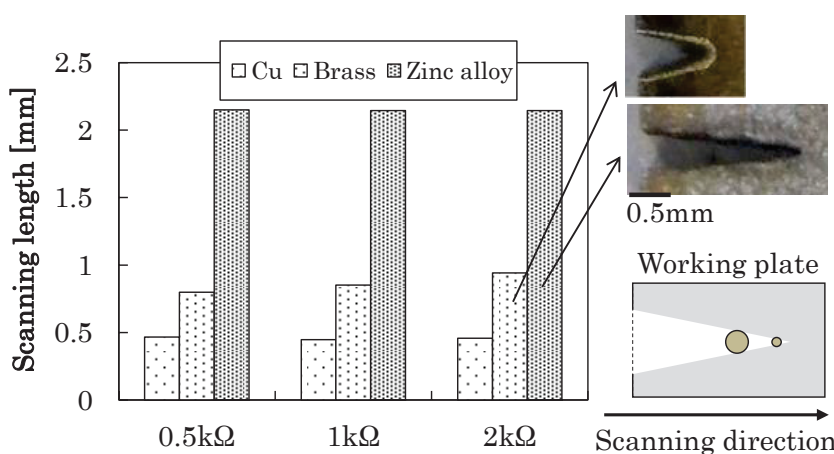

Fig. 8 Scanning length 100 micrometer in diameter

倣うように消耗し，その消耗形態はFig. 7 に示寸 ような概ね三角形状となる（正確には, 台形と半 円の合成形状).Fig. 8 に成形プレートを各種材 料（銅，黄銅，亜鉛合金）とした場合の電気条件 が走査距離に及ぼす影響を示す。走査距離は, 軸

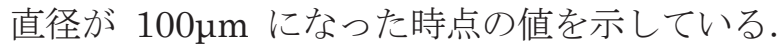
3 種類の材料において電気条件による走査距離 の差はほとんど確認できないが, 走査距離は大き く異なる。それぞれの走査距離は，銅，黄銅で $1 \mathrm{~mm}$ 以下，亜鉛合金では $2 \mathrm{~mm}$ を超えた結果と なり, 各材料での消耗比の違いよって走査距離は 大きく変化したといえる.

以上の結果から，走查距離を指標とした場合に は，放電パルス一定の条件下では，放電頻度，軸 長さに依存ぜず，走查距離は材料の組み合わせに よる消耗比によってのみ決定される，このため， 走査距離を指標とする軸直径の推定は有効な方法 であると考えられる.

\section{3. 軸成形の幾何学的モデル}

これまでの結果から，走查距離と消耗比によっ て軸直径が推定されると考えられる。つまり，実 験によって，ある材料の組み合わせでの電気条件
下における消耗比が決定されれば，幾何学モデル から走查距離によって軸直径を推定できると考え られる，本章では，以下に示す幾何学モデルによ って, 軸直径の推定の可能性を検証する.

\section{1 走査距離における軸直径}

厚さ一定のプレートを用いた軸成形走查加工を 考える。軸と成形プレートの単位体積あたりの消 耗比が一定と仮定した場合，軸直径と消耗比の関 係は(1)式で表せる. $\left(V_{p}\right.$ : 成形プレート除去体積, $V_{e}$ : 軸の除去体積, $\alpha$ : 単位体積あたりの消耗比)

$$
V_{p}=\alpha V_{e}
$$

軸の除去体積は走査距離に依存せず(2)式で表 される

$$
V_{e}=\left(\pi r_{0}^{2}-\pi r^{2}\right) l
$$

ただし, $r_{0}$ : 軸の初期半径, $r$ : 成形後の軸半 径， $l$ : 軸長さである.

第 2.3 節で述べたように，成形プレートは軸の 微細化に倣うように消耗し，その消耗形態は，台 形と半円の合成形状となる。 そのため, 成形プレ

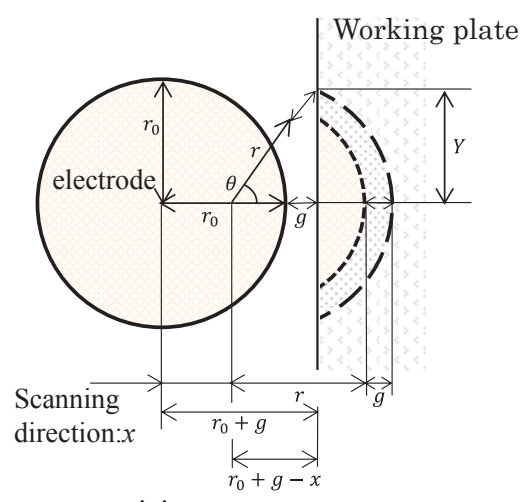

(a) $x<r_{0}+g$

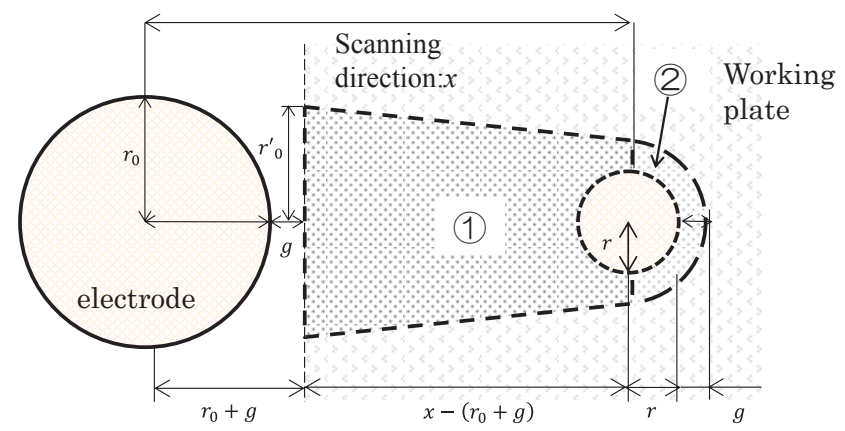

(b) $x \geqq r_{0}+g$

Fig. 9 Schematic view of electrode and working plate 
一トの除去体積は，軸の中心がプレート端面に達 する前後で異なる.

$x$ を加工開始点（接触位置-初期放電極間距離） から加工進行方向にとった軸中心変位とした場合, $x<r_{0}+g$ では, 成形プレートの加工形状は半円 となり, Fig.9(a)に示すようになる。またその場 合の，除去体積 $V_{p}$ は(3)式で表せる. ただし， $Y$ : 成形プレート端面における加工幅の半分, $\theta$ : 軸 中心から成形プレートへの入口角度, $g:$ 極間距 離であり，それぞれ(4)式および(5)式に示す．消耗 比 入することで, 走査距離 $x$ と成形後の軸半径 $r$ が求 まる。また，軸の初期半径 $r_{0}$ は実験で用いている 值 $0.25 \mathrm{~mm}$ （軸直径 $0.5 \mathrm{~mm}$ ）とした.

$V_{p}=\left\{\pi[(r+g)]^{2} \times \frac{\theta}{\pi}-\left(r_{0}+g-x\right) Y\right\} l$

$$
\begin{gathered}
\text { for } \theta<\frac{\pi}{2} \\
Y=\sqrt{(r+g)^{2}-\left(r_{0}+g-x\right)^{2}} \\
\theta=\sin ^{-1} \frac{Y}{r+g}=\sin ^{-1} \frac{\sqrt{(r+g)^{2}-\left(r_{0}+g-x\right)^{2}}}{r+g}
\end{gathered}
$$

一方, $x \geqq r_{0}+g\left(\theta=\frac{\pi}{2}\right)$ では, 軸中心が成形プ レートの端面より成形プレート内部に侵入する. この場合の成形プレートの加工形状は, 台形と半 円の合成形状となり，Fig.9(b)に示寸，そこで, 除去体積 $V_{p}$ は台形と半円の各面積に厚みを掛けた ものの和となり，(6)式で表せる。ただし， $r_{0}^{\prime}$ は $x=r_{0}+g$ における成形プレート加工幅の半分で

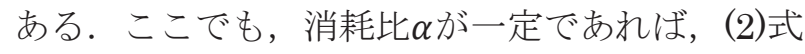
および(6)式を(1)式一代入することで，走査距離 $x$ と成形後の軸半径 $r$ 飡まる.

$V_{p}=\left\{\left(r_{0}^{\prime}+2 g+r\right)\left[x-\left(r_{0}+g\right)\right]+\frac{\pi(r+g)^{2}}{2}\right\} l$

\section{2 軸直径と消耗比の関係}

前節で提案したモデルを検証するために実加工 と比較した．放電条件は $\mathrm{C}=47000 \mathrm{pF}, \mathrm{R}=1 \mathrm{k} \Omega$, $\mathrm{E}=80 \mathrm{~V}$ とし, 成形プレートには亜鉛合金 $(l=1 \mathrm{~mm})$ を用いた. Fig. 10 に走查放電加工後の成形プレー

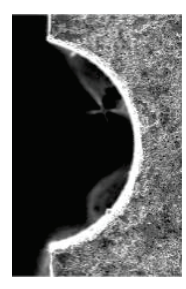

(a) $x \leqq r_{0}+g$

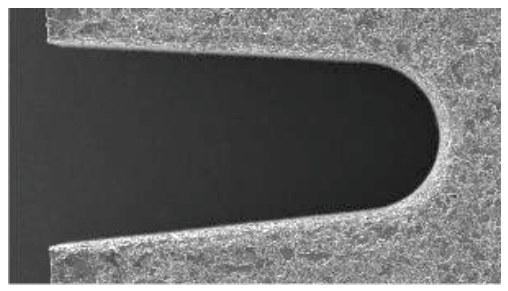

$0.5 \mathrm{~mm}$
Fig. 10 SEM image of working plate

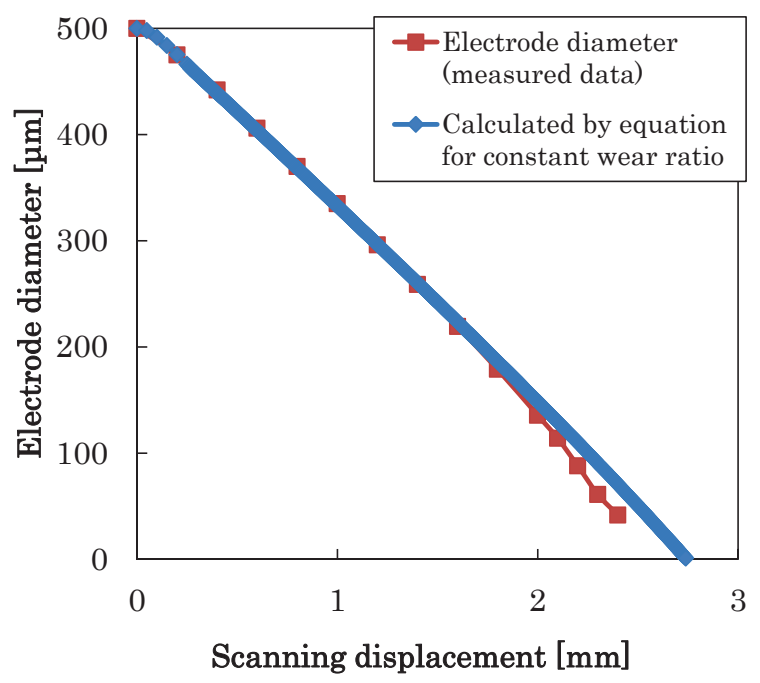

Fig. 11 Relation between diameter and scanning length with caluculated by equation

ト SEM 像を示す. (a)は走査距離 $x=0.2 \mathrm{~mm}$ の結 果であり，加工部は軸半径より小さい。一方，(b) は走查距離 $x=1.0 \mathrm{~mm}$ であり, 軸の微細化に伴っ て成形プレートの加工部形状が台形+半円の合成 形状となっている.

Fig. 11 に軸直径と走査距離の関係を示す.また, 同図には, 第 3.1 節で算出した(3)式および(6)式か ら得られた計算結果も示寸．消耗比 $\alpha$ は，500 $\mu \mathrm{m}$ から $300 \mu \mathrm{m}$ の軸を成形した際の加工における成 形プレートおよび軸直径の実測データから求めた $(\alpha=3.4)$.また, 極間距離は, 安定な加工位置 から被加工物一の電気的な接触によって求めた $(g=17 \mu \mathrm{m})$. 軸直径 $150 \mu \mathrm{m}$ 程度までは, 計算結 果と実験結果が比較的よく一致するが，軸直径が 小さくなると，わずかに計算結果とは一致しない 傾向を示した。これまでの結果から，消耗比によ って走查距離と軸直径が決定されると考えられた が, 軸直径 $100 \mu \mathrm{m}$ 程度以下では一致しない結果 
となった。

計算值と一致しない原因としては，消耗比 $\alpha$ が 軸直径の微細化に伴って変化することが挙げられ る. 実際に軸直径 $100 \mu \mathrm{m}$ 前後の軸直径で計測し た消耗比 $\alpha$ は，2.7であった。これは，軸直径が細 くなることにより熱抵抗が大きくなり 8)，軸の消 耗量が増大したためと考えられる。この制御方法 においては軸直径が小さくなるに伴って変化する 消耗比についても考慮する必要があることが明ら かとなった。また，成形プレートに亜鉛合金を用 いて走查距離 $2.3 \mathrm{~mm}$ とした軸を成形した結果, 成形された軸直径は $57 \sim 67 \mu \mathrm{m}$ の間でバラツキが 生じた。この原因は別途調査する必要があるが, 簡易的な方法によって $10 \mu \mathrm{m}$ 以内の精度で微細な 軸を容易に成形することが可能となった。

\section{4. 結言}

本研究では，走查放電加工法を用いた微細軸を 成形し, 走査距離と軸直径の関係を明らかにした。 本論文で得られた結論は以下のとおりである。

（1）走査放電加工法を用いた軸成形において，軸 の微細化に伴って放電頻度は減少する。これ は, 放電面積の減少が原因として考えられる.

(2) 充電抵抗を変えることで放電頻度は大きく異 なる。しかし，走查距離と軸直径の関係には 相異はなく, 同一パルス加工条件を用いれば, 走査距離は一定である。

（3）成形プレートに各種材料（銅，黄銅，亜鉛合 金）を用い走查距離を調査した結果，銅で $0.46 \mathrm{~mm}$ ，黄銅で $0.87 \mathrm{~mm}$ ，亜鉛合金は $2.15 \mathrm{~mm}$ であった。また，放電頻度による走 査距離の影響は認められなかった。

（4）成形プレートに亜鉛合金を用い，成形する軸 の長さを $1 \mathrm{~mm} ， 2 \mathrm{~mm}$ および $5 \mathrm{~mm}$ とし，加 工条件を同じとした場合，走査距離と軸直径 の関係は一定であった。
（5）軸と成形プレートの単位体積あたりの消耗比 を一定と仮定した場合, 軸直径 $150 \mu \mathrm{m}$ 程度ま では，計算結果と実験結果がよく一致した。 しかし, 軸直径が 100 $\mathrm{\mu m}$ 以下になると消耗比 が小さくなり，計算結果と実験結果は異なっ た.

\section{謝 辞}

本研究の遂行にあたり，ご指導くださった工学 院大学 武沢英樹教授に厚く御礼申し上げます.

\section{参 考 文 献}

1）平尾篤利, 谷貴幸, 武沢英樹, 毛利尚武 : 放電 電極成形における微細化限界の一考察, 2012 年 度精密工学会春季大会，（2012）pp.133-134.

2) 増沢隆久, 藤野正俊: 高精度微細加工の研究 (第 1 報）-ワイヤ放電研削法の開発-，電気加工学会 誌, Vol.24, No.48 (1991) pp.14-28.

3) T.Masuzawa, M.Fujino, K.Kobayashi : Wire Electro Discharge Grinding for MicroMachining, Annals of the CIRP, Vol.34, No.1 (1985) pp.431-434.

4）南久, 増井清徳, 塚原秀和, 萩野秀樹: 亜鉛電極 による高能率微細放電加工, 生産加工・工作機械 部門講演会論文集，（2004）pp.297-298.

5）山崎実，森紀年，鈴木岳美，國枝正典：軸穴同 時マイクロ放電加工法の研究, 精密工学会誌,

Vol.69, No.7 (2003) pp.944-948.

6) 谷貴幸, 後藤啓光, 毛利尚武, 齋治男: 走査放電 加工による微細軸成形に関する研究(第 2 報)-プレ 一下材料,電気条件が微細軸成形特性に及ぼす影 響-, 電気加工学会全国大会(2006)講演論文集, (2006) pp47-48.

7）谷貴幸, 後藤哲光, 李珠瓊, 毛利尚武: 走查放電 加工による微細軸成形法, 電気加工学会誌, Vol.43, No.104 (2009) pp.187-193.

8）向山芳世, 楊友沈: 放電加工における溶解層の 3 次元解析, 電気加工学会誌, Vol.26, No.53 (1991) pp.13-24.

(2013年3月6日受付) 